\title{
Structural and Lithological Study of Gold Mineralization in the Areas of Bena and Bakolobi, Mali, West Africa
}

\author{
Fodé Tounkara ${ }^{1,2 *}$, Jianguo Chen ${ }^{1,2}$, Ahmed Amara Konaté3, Chengbin Wang ${ }^{1,2}$ \\ ${ }^{1}$ State Key Laboratory of Geological Processes and Mineral Resources, China University of Geosciences (Wuhan), Wuhan, China \\ ${ }^{2}$ Faculty of Earth Resource, China University of Geosciences (Wuhan), Wuhan, China \\ ${ }^{3}$ Institute of Geophysics and Geomatics, China University of Geosciences (Wuhan), Wuhan, China \\ Email: ^fode1986@yahoo.fr
}

How to cite this paper: Tounkara, F., Chen, J.G., Konaté, A.A. and Wang, C.B. (2017) Structural and Lithological Study of Gold Mineralization in the Areas of Bena and Bakolobi, Mali, West Africa. Open Journal of Geology, 7, 1318-1326. https://doi.org/10.4236/ojg.2017.79087

Received: July 10, 2017

Accepted: September 8, 2017

Published: September 11, 2017

Copyright $\odot 2017$ by authors and Scientific Research Publishing Inc. This work is licensed under the Creative Commons Attribution International License (CC BY 4.0).

http://creativecommons.org/licenses/by/4.0/ (c) (†) Open Access

\begin{abstract}
The areas of Bena-Bakolobi are located in the eastern part of the KedougouKenieba in layer. This sector contains several deposits of gold, including the mines of Sadiola, complex Gara-Yalea and Gounkoto, gold mines of Tabakoto and the gold deposit of Fekola, all located around the (SMS) Senegalo Malian shear zone. The work carried out is summarized in two parts: The first part is based on the detailed mapping of the Bena and Bakolobi target. It was necessary to make a detailed mapping in order to understand and assess the target. The second part is to determine the term and the litho-structural control of gold mineralization. This study is based on lithology, alteration, structures and mineralization of the two areas. The ultimate purpose is to draw a regolith map for a future research program. Two types of alteration affect the rock formations of the two zones: weathering (supergene) that consists in hematization, limonitisation and the kaolinitization. The hydrothermal alteration consists in albitization, chloritisation, the sericitization, the tourmalinisation, the sulphidation, silicification and carbonation. This paper improves structural and lithological study of gold mineralization in the areas of Bena and Bakolobi. The analysis of the results of the work carried out in the two zones allowed us to have an overview on the geology of these two zones, which are located in the Kédougou-Kéniéba window in the volcano-sedimentary rocks of Proterozoic Formation of Kofi. The lithological and structural studies carried out in the area have demonstrated the relationship between structures and mineralization and/or lithology.
\end{abstract}

\section{Keywords}

Bena-Bakolobi, Gold Mineralization, Regolith, Volcano-Sedimentary Rocks 


\section{Introduction}

The area of Bena-Bakolobi is located in the eastern part of the Kedougou Kéniéba buttonhole. This area contains several gold deposits, all located in the vicinity of the Senegal-Malian shear zone (SMS) on the Kofi formation. These gold deposits, combined with gold panning and artisanal mining, underscore the highly promising character of the area. In Mali, a less developed country, gold export has substantially increased in the 1990s [1]. Mali suffers from artisanal and small-scale mining formalization problem as other mineral rich countries in the region [2]. It argues that the child labor, which is now widespread in many of the region's small-scale mining communities, is a product of a combination of cultural issues, household-level poverty, and rural livelihood diversification [3].

The study area is administratively attached to the Kéniéba circle, Kayes region in western Mali, near the Falémé river (natural border between Mali and Senegal). Located in $350 \mathrm{~km}$ west of Bamako, $250 \mathrm{~km}$ south of Kayes, Bakolobi is 12 $\mathrm{km}$ north of the Fekola and Bena, $15 \mathrm{~km}$ south of the Gounkoto gold mine. The ultimate purpose is to draw a regolith map for a future research program. The method which will be used is quick and cost-effective. According to the available literature [4], [5], [6] and [7], there is limited research on gold resource in Mali.

\section{Geological Setting}

\subsection{Regional Geology}

The West African Craton: In 1663 - 1665, Rocci described the African continent as consisting of several blocks welded together by folded belts separated by moving zones. The West African craton, identified by Kennedy in 1964 is that part of West Africa

Consisting of Archean and lower Proterozoic ages, stabilized around 1600 1500 million years ago. It is partially covered with more recent Proterozoic formations higher than at present in its central part: the Taoudeni Basin. It is bordered to the west by the poly-orogenic belts of the Mauritanides and Rockelides (Panafricain and Hercynian); to the north by the Hercynian domain of the Anti-Atlas; In the East by the Pan-African, Pharisee and Dahomean belts.

The structuring of the West African Craton shows three units of outcrops: to the north the Reguibat ridge, to the south the ridge of Leo, have a great extension, the middle part windows of Kayes and Kéniéba is small but constitutes a landmark Important between The other outcrop areas (Figure 1).

\subsection{Local Geology}

From a geological point of view, the study area is located in the Birrimian formations of the Kédougou-Kéniéba window. The northwestern part of the Bakolobi zone is located in the volcano-sedimentary rocks of the Birrimian, while the southeast zone is interpreted as granitoid. Towards the east, the upper Proterozoic sandstones have been deposited unconformably on the Birrimian formations and the rate of outcrop of the zone is about $5 \%$. The relief of this region is 


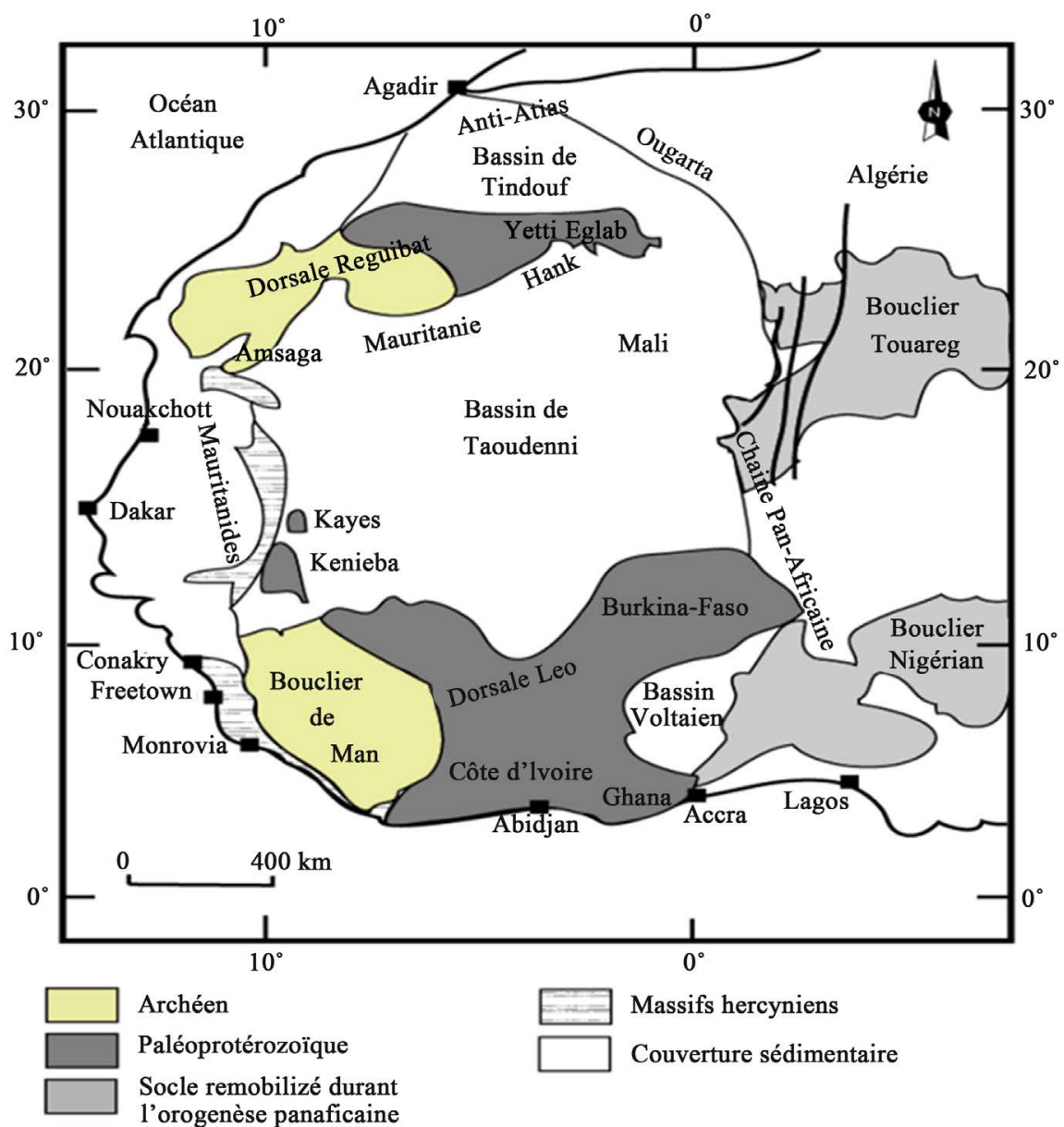

Figure 1. Geological map and study area located in Kenieba (west African craton, source BRGM).

constituted by a peneplain dominated to the east by the plateau of the Tambaoura which is oriented NNW-SSE with 200 to $250 \mathrm{~m}$ of altitude. The peneplain corresponds to the region of the Bambouk or buttonhole of the base of Kédougou-Kéniéba, whose average altitude is of the order of a hundred meters.

\section{Data and Research Methodology}

Those maps of regolith have been established by a methodology, which consists of following lines along which are mapped on millimeter paper, the different facies, outcrops, armored plateaus, roads, drainage channels etc. The lines are spaced $100 \mathrm{~m}$ apart and total 24 lines. After field mapping, the carry-over is immediately carried out in parallel with the regolith mapping on a base map (scale 1:2000). To close the different polygons, a correlation is made between the boundaries of similar facies. Once the map is established, it will be crowned by a computer operation, which consists of scanning or to photograph this map. With the Geographic Information System (GIS), these maps have been digitized and added geological information. During the geological work, samples were collected for analysis at the laboratory. It was necessary to make a detailed map- 
ping in order to understand, to assess the target, to determine the term and the litho-structural control of gold mineralization.

\section{Results and Discussion}

The result obtained is the present regolith maps (Figure 2). The dominant regime is the residual cuirass regime and some greywackes outcropping salaries and breach. In the mapped area (Figure 3), there are three (3) regimes, namely:

1) The cuirass regime represents about $85 \%$;

2) The erosion regime represents about $5 \%$;

3) The depositional regime represents about $10 \%$.

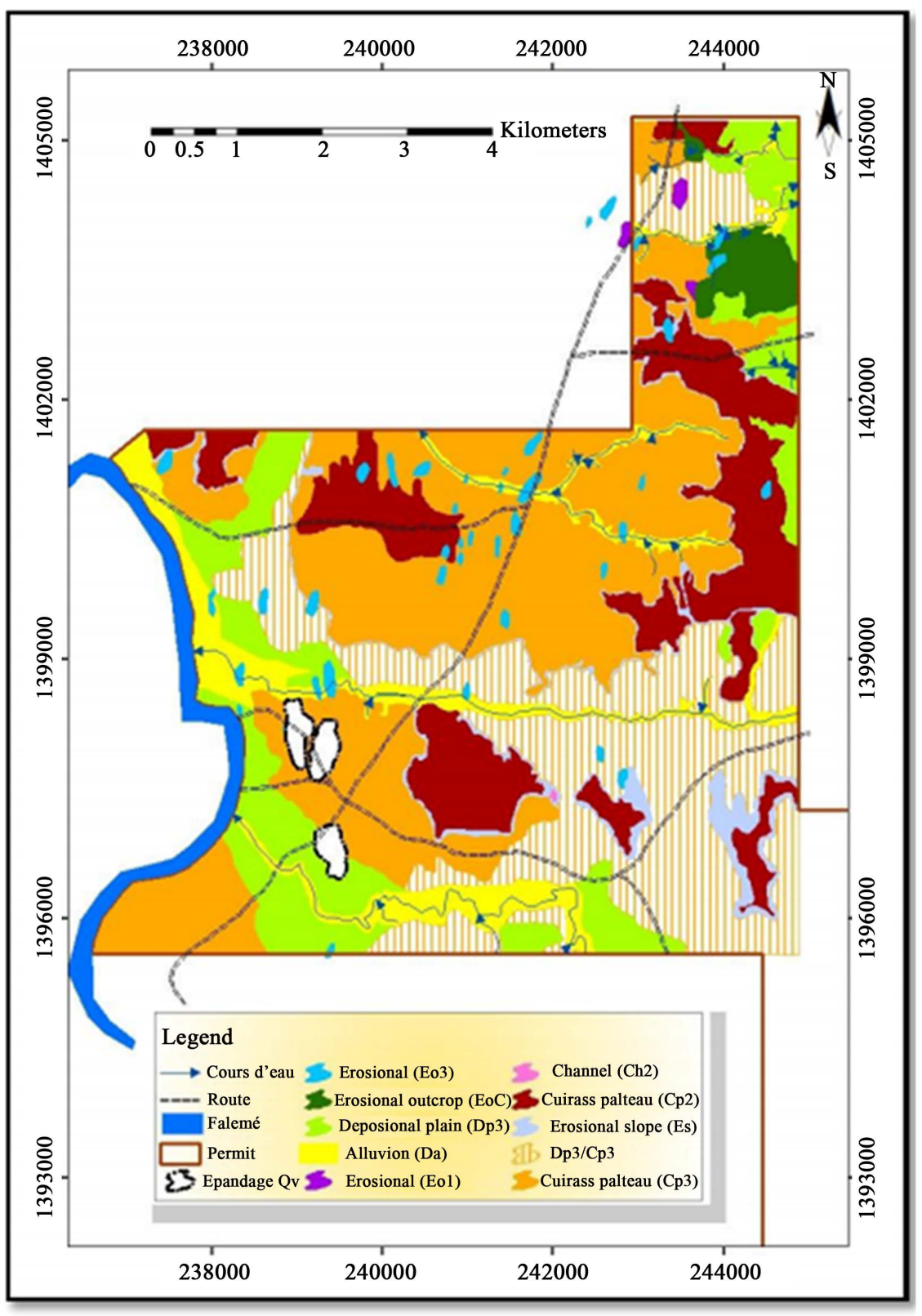

Figure 2. Regolith of the northern part of Bakolobi. 


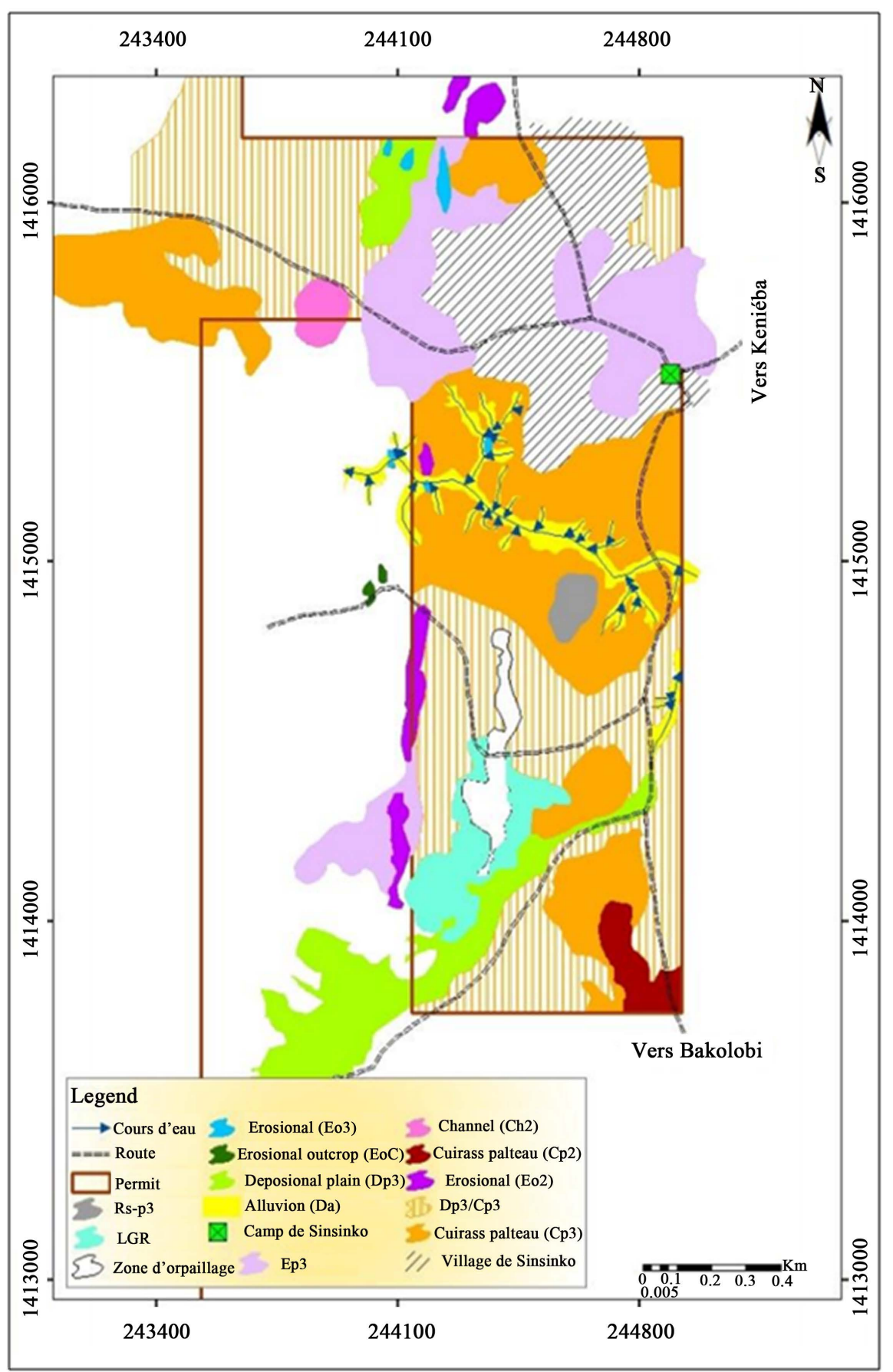

Figure 3. Sinsinko target regolith (Bena area).

Two types of alteration affect the rock formations of the two zones: weathering (supergene) that consists in hematization, limonitisation and the kaolinitization. The hydrothermal alteration consists in albitization, chloritisation, the sericitization, the tourmalinisation, the sulphidation, silicification and carbonation.

Measured structures: Many structures were measured in the trench. These structures are represented on the following stereogram in (Figure 4 and Figure $5)$. 


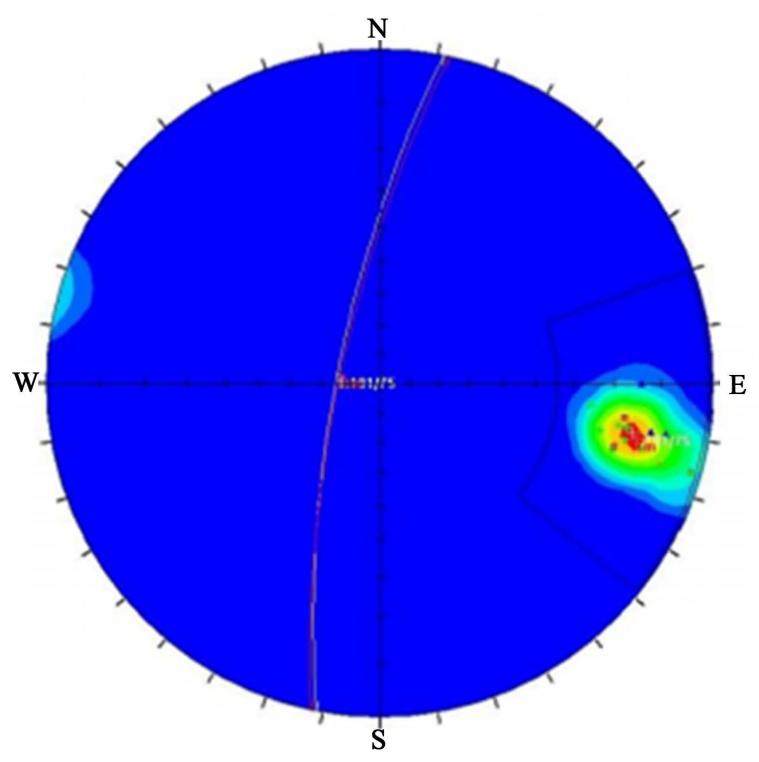

TYPE STRUCTURE

- Bed [3]

- Con [3]

- Sh [8]

Vqz [1]

BKTR009

Figure 4. Wulf pattern of the structures measured in the trench No. BKTR009. According to the stereogram, these structures have a general direction N191/75 with a strong dip.

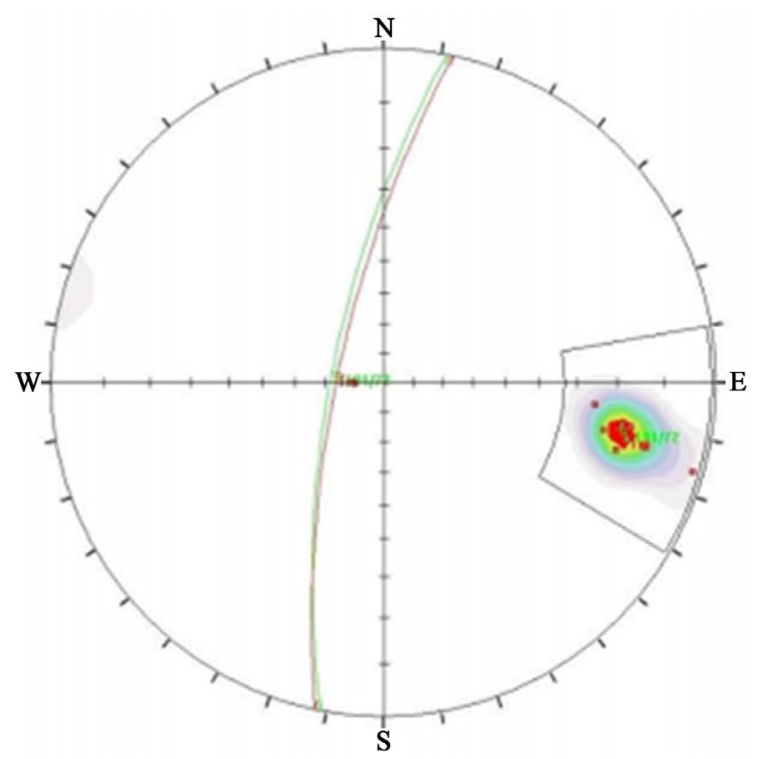

TYPE STRUCTURE
Equal Angle
Lower Hemisphere
15 Poles
15 Entries

Figure 5. Wulf pattern of shear measured in trench No. BKTR009, the shear in trench No. BKTR009 has a general direction N191/72 with a strong dip.

\subsection{Relationship between Mineralization and Structures}

1) In the Dioula target, mineralization was observed in three sediments. This allows us to conclude that the mineralization in this target therefore has no lithological control. It appears mainly linked to the structures and therefore has structural control. Several mineralized zones have been intercepted; Controlled by steering structures with shear NNE-SSW steering and N-S steering structures.

2) In the Gamaye target, mineralization has structural control. It appears mainly linked to structures. Three mineralized zones were intercepted, controlled by NNW-SSE shear structures. 
3) In the Koliguinda target, some lithologies are affected by mineralization. It appears mainly linked to the structures and therefore has structural control. Three mineralized zones were intercepted; Controlled by steering structures with NNW-SSE steering shears and NW-SE steering structures. However, gold deposits in the Syama and Tabakoroni goldfields in southern Mali occur along a north-northeast trending mineralised litho-structural corridor that trends for approximately $40 \mathrm{~km}$ [8].

We notice that the primary gold mineralisation at Yatela is low-grade and sub-economic [9]. However, gold mineralization at Morila is hosted in flat-lying meta-graywacke associated with a Birimian-aged Massigui schist belt in Mali [10].

Even though the three gold occurrences are aligned along the same major structure, each one has distinct geological features including the nature of the dominant host rock in the mineralized zone (for example a basaltic volcanic sequence at Syama, a diorite pluton at Tellem and a felsic volcanic sequence at Tabakoroni) [11].

\subsection{Relationship between Mineralization and Lithology}

The interpretation of the various works carried out in the zone showed that the mineralization is dispersed in the locally brecciated quartzite.

Some lithologies are affected by mineralization. It appears mainly linked to the structures and therefore has structural control. Controlled by structures with intense shear N-S. However, in the other zones:

We notice that the Alamoutala gold deposit is part of the Yatela gold district, which is located in the Kédougou-Kénieba inlier (KKI), a window of deformed Birimian rocks (Paleoproterozoic, ca. 2200 - $2050 \mathrm{Ma}$ ) that outcrop in eastern Senegal and western Mali [12].

While the Loulo-Gounkoto complex in the Kédougou-Kéniéba Inlier hosts three multi-million ounce orogenic gold deposits, situated along the Senegal-Mali Shear Zone [13].

Therefore, the interaction of hydrothermal fluids with metamorphosed carbonaceous matter (CM) could be one of the causes of the reduction of hydrothermal fluids and formation of the respective mineralization [14].

The further comprehensive interpretation concern a process separating freshly-panned gold concentrate from residual mineral inclusions.

\section{Conclusions}

This paper improves structural and lithological study of gold mineralization in the areas of Bena and Bakolobi. The analysis of the results of the work carried out in the two Bena-Bakolobi zones allowed us to have an overview on the geology of these two zones, which are located in the Kédougou-Kéniéba window in the volcano-sedimentary rocks of Proterozoic Formation of Kofi Formation. The lithological and structural studies carried out in the area have demonstrated the 
relationship between structures and mineralization and/or lithology. The main characteristics of the gold mineralization in the Bakolobi zone appear to indicate hydrothermal mineralization in connection with a shear zone.

The process of structural and lithological study in this work indicates two aspects.

Firstly, the interpretation of the various works carried out in the zone showed that the mineralization is dispersed in the locally brecciated quartzite.

Secondly, some lithologies are affected by mineralization. It appears to be mainly linked to the structures and therefore has structural control.

\section{Acknowledgements}

The Minister of Mining of Mali under (Bena-Bakolobi project 2015), that we would like to thank sincerely, has financially supported this study research. Special thanks to my supervisor in state key laboratory of geological processes and mineral resources, China University of Geosciences, Wuhan. Thanks also all colleagues from National School of Engineers Abderhamane Baba TOURE of MALI for advice.

\section{References}

[1] Mainguy, C. (2010) Natural Resources and Development: The Gold Sector in Mali. Ore Geology Reviews, 36, 123-131.

[2] Teschner, B.A. (2011) Orpaillage Pays for Everything: How Artisanal Mining Supported Rural Institutions Following Mali's coup d'etat. Futures, 62,110-150.

[3] Feybess, G. (2006) Explanatory Note of the Geological Map of the Republic of Mali at 1 / 200, 000. Unpublished Report.

[4] Feybesse (2006) Geological Synthesis of the Malian Birimian Edition Sysmin. Unpublished Report.

[5] Jean-Louis, F., Sidibé, Y.T., Konaté, C.M., Lacomme, A., Guerrot, C., Miehé, J., Lamberti, A., Zammit, C., MMIT5, BRGM, CPG and DNGM (2006) Carte géologique de la République du Mali à 1/200000, Feuille $\mathrm{n}^{\circ}$ NC-29-XXII, Yanfolila-Bamako (MALI). Ministère des Mines, de l'énergie et de l'Eau.

[6] Hilson, G. (2012) Family Hardship and Cultural Values: Child Labor in Malian Small-Scale Gold Mining Communities. World Development, 40, 1663-1674. https://doi.org/10.1016/j.worlddev.2012.03.017

[7] Ibrahima Ballo, K.A.A.H., Guindo, B., Sanogo, L., Yalema-Ouologuem, Daou, G. and Traore, A. (2015) The Syama and Tabakoroni Goldfiefd, Mali. Ore Geology reviews, 78, 578-585.

[8] Masurel, Q., Thébaud, N., Mille, J., Ulrich, S., Hein, K.A.A., Hanssen, E., Kaisin, J. and Tessougue, S. (2015) The Yatela Gold Deposit in Mali, West Africa the Final Product of Long-Lived History of Hydrothermal Alteration and Weathering. Journal of African Earth Sciences, 113, 73-87. https://doi.org/10.1016/j.jafrearsci.2015.10.006

[9] Hammond, N.Q., Robb, L., Foya, S. and Ishiyama, D. (2011) Mineralogical, Fluid Inclusion and Stable Isotope Characteristics of Birimian Orogenic Gold Mineralization at the Morila Mine, Mali, West Africa. Ore Geology Reviews, 39, 218-229. https://doi.org/10.1016/j.oregeorev.2011.03.002 
[10] Masurel, Q., Thébaud, N., Miller, J., Ulrich, S. and Hein, K.A.A. (2015) The Alamoutala Carbonate-Hosted Gold Deposit in Mali, West Africa. Economic Geology, 112, 49-72. https://doi.org/10.2113/econgeo.112.1.49

[11] Lambert-Smith, J.S., Lawrence, D.M., Vargas, C.A., Boyce, A.J., Treloar, P.J. and Herbert, S. (2015) The Gounkoto Au deposit, West Africa: Constraints on Ore Genesis and Volatile Sources from Petrological, Fluid Inclusion and Stable Isotope Data. Ore Geology Reviews, 78, 606-622. https://doi.org/10.1016/j.oregeorev.2015.10.025

[12] Kríbek, B., et al. (2015) The Origin and Hydrothermal Mobilization of Carbonaceous Matter Associated with Paleoproterozoic Orogenic-Type Gold Deposits of West Africa. Precambrian Research, 270, 300-317. https://doi.org/10.1016/j.precamres.2015.09.017

[13] Rehren, Th. and Nixon, S. (2014) Refining Gold with Glass-An Early Islamic Technology at Tadmekka, Mali. Journal of Archaeological Science, 49, 33-41. https://doi.org/10.1016/j.jas.2014.04.013

[14] Traoré, Y.D., Siebenaller, L., Salvi, S., Béziat, D. and Bouaré, M.L. (2015) Progressive Gold Mineralization along the Syama Corridor, Southern Mali (West Africa). Ore Geology Reviews, 78, 586-598. https://doi.org/10.1016/j.oregeorev.2015.11.003

Submit or recommend next manuscript to SCIRP and we will provide best service for you:

Accepting pre-submission inquiries through Email, Facebook, LinkedIn, Twitter, etc. A wide selection of journals (inclusive of 9 subjects, more than 200 journals)

Providing 24-hour high-quality service

User-friendly online submission system

Fair and swift peer-review system

Efficient typesetting and proofreading procedure

Display of the result of downloads and visits, as well as the number of cited articles

Maximum dissemination of your research work

Submit your manuscript at: http://papersubmission.scirp.org/

Or contact ojg@scirp.org 